\title{
Artificial Intelligence Market Disruption
}

\author{
Julia M. Puaschunder ${ }^{1,2,3}$ \\ ${ }^{1}$ The New School, Department of Economics, 6 East $16^{\text {th }}$ Street, $9^{\text {rd }}$ floor 89, New York, NY 10003, USA, \\ Julia.Puaschunder@newschool.edu,T001 212229 5700,F 001212229 5724,www.juliampuaschunder.com \\ ${ }^{2}$ Columbia University, Graduate School of Arts and Sciences, Julia.Puaschunder@columbia.edu, \\ http://blogs.cuit.columbia.edu/jmp2265 \\ ${ }^{3}$ Princeton University, Graduate School of Arts and Sciences, Julia.Puaschunder@princeton.edu
}

\begin{abstract}
The introduction of Artificial Intelligence (AI) in our contemporary society imposes historically unique challenges for humankind. The emerging autonomy of AI holds unique potentials of eternal life of robots, AI and algorithms alongside unprecedented economic superiority, data storage and computational advantages. Yet to this day, it remains unclear what impact AI taking over the workforce will have on economic growth.
\end{abstract}

KEYWORDS: AI, AI-GDP Index, AI market entry, Artificial Intelligence, capital, economic growth, endogenous growth, exogenous growth, Global Connectivity Index, GDP, Gross Domestic Product, labor, law and economics, society, State of the Mobile Internet Connectivity, workforce

\section{Introduction}

The contemporary trend of slowbalisation is described, as the slowing down of conventional globalization of goods, services and Foreign Direct Investments (FDI) flows; yet at the same time, we still see human migration and air travel as well as data transfer continuing to rise. These market trends of conventional globalization slowing and rising AI-related industries are proposed as first market disruption in the wake of the large-scale entrance of AI into our contemporary economy. Growth in the artificial age is then proposed to be measured based on two AI entrance proxies of Global Connectivity Index and The State of the Mobile Internet Connectivity 2018 Index, which is found to be highly significantly positively correlated with the total inflow of migrants and FDI inflow - serving as evidence that the still globalizing rising industries in the age of slowbalisation are connected to AI. Both indices are positively correlated with GDP output in cross-sectional studies over the world. In order to clarify if the found effect is a sign of industrialization, time series of worldwide data reveal that internet connectivity around the world is associated with lower economic growth from around 2000 on until 2017. A regression plotting Internet Connectivity and GDP per capita as independent variables to explain the dependent variable GDP growth outlines that the effect for AI is a significant determinant of negative GDP growth prospects for the years from 2000 until 2017. A panel regression plotting GDP per capita and internet connectivity from the year 2000 to explain economic growth consolidates the finding that AI-internet connectivity is a significant determinant of negative growth over time for 161 countries of the world. Internet connectivity is associated with economic growth decline whereas GDP per capita has no significant relation with GDP growth. To cross-validate both findings hold for two different global connectivity measurements. The paper then discusses a theoretical argument of dividing labor components into fluid, hence more flexible (e.g., AI), and more clay, hence more inflexible (e.g., human labor), components. The paper ends on a call for revising growth theories and integrating AI components into growth theory. AI entrance into economic markets is modeled into the standard neoclassical growth theory by creating a novel index for representing growth in the artificial age comprised of GDP per capita and AI entrance measured by the proxy of Internet Access percent per country. Maps reveal the parts of the world that feature high GDP per capita and AI-connectivity. The discussion closes with a future outlook on the law and economics of AI entrance into our contemporary economies and society in order to aid a successful and humane introduction of AI into our world.

\section{Research Question}

Already now, about 28 percent of the workforce in modern economies are estimated to be based on AI or AI-supported (Fraad-Wolff, in speech). First market disruptions of AI entering economies are currently speculated to cause a trend of slowbalisation - as a counter-trend to globalization. Globalization sprang 
from America's sponsorship of a new world order in 1945, which allowed cross-border flows of goods and capital to recover after years of war and chaos (Centeno, Creager, Elga, Felton, Katz, Massey \& Shapiro 2013; Centeno, \& Tham 2012). During the golden age of globalization from 1990-2010 the world became flat: Immigration increased from 2.9 to 3.3 percent of the world's population and global trade grew from 39 percent of GDP in 1990 to 58 percent last year (The Economist, January 26, 2019). Asia became part of the globalized upon China's entry into the WTO in 2001, which created a model of offshoring manufacturing to countries based on cost efficiency variances, primarily labor costs (Profita 2019). The Washington Consensus embraced the world and promised to bring prosperity to everyone around the globe (Rodrik 2006). Open markets and free trade were praised to lift billions of people out of poverty in Asia, Latin America and Africa via economic growth (Held \& McGrew 2007).

With the collapse of the Soviet Union in 1989 and the end of the Cold War in 1991, the world became even more interconnected and global market economies integrated around the world. Trade and investment increased, while barriers to migration and cultural exchange lowered (Mohamed, 2016). The European Union but also free trade agreements, such as the North American Free Trade Agreement (NAFTA), which the governments of the United States, Canada, and Mexico signed in 1992, removed barriers to the free flow of people, goods, and services, thereby facilitating greater trade, investment, and migration across borders in an unprecedented way (Profita 2019; Puaschunder 2018b; World Bank Group Migration and Development Brief 26, 2016).

During the last 17 years, China increased its GDP from $\$ 1.2$ trillion to $\$ 11$ trillion, a sign of historically unprecedented growth for a country of this size (Profita 2019). A similar phenomenon occurred in India, Vietnam and other countries. Globalization also supported the growth of large multinational companies that offshored production processes and consumers to access an endless number of products at competitive prices from around the globe. Commerce soared as the cost of shifting goods in ships and planes fell, phone calls got cheaper, tariffs were cut and finance liberalized. Business went gangbusters as firms set up around the world, investors roamed and consumers shopped in supermarkets with goods from around the globe (Profita 2019). As never before in history, traveling had become available to the general populace at affordable prices. The number of refugees reached all-time highs. If not moving oneself, free data services provided on the 'window to the world' internet, allowed everyone to consume the globe anytime anywhere.

Yet, globalization also brought about negative consequences and unforeseen shadows of the invisible hand. Until the 1990s, studies report no connection between GDP and happiness - yet from the 1990s on there is a negative correlation found between GDP and happiness (Kirchler 2011). This trend is attributed to the internet and access to information about other places on earth's living conditions creating emotionally-hurtful comparisons in desolate places, also fueling migration trends, which has never been higher as now.

\section{Theory}

When America took a protectionist turn in its 2016 Presidential election they were, once again, first in sensing and acting on a contemporary detected, most novel worldwide trend: We currently live in the age of slowbalisation. Protectionism, trade wars, emerging economies' slowdown and the decrease in goods and services trade as well as a slump in transnational investments are all signs of the global trend of globalization have come to a halt. United Kingdom followed shortly after the US presidential with voting for Brexit. Globalization has slowed in our current times of 'slowbalisation,' a term coined in 2015 by Adjiedj Bakas, who sensed first that globalization has given way to a new era of sluggishness.

Globalization has slowed in the past decade after the 2008 global recession. Trade has fallen from 61 percent of world GDP in 2008 to 58 percent now (The Economist, January 26, 2019). If these figures exclude emerging markets (of which China is one), it has been flat at about 60 percent (The Economist, January 26, 2019). The capacity of supply chains that ship half-finished goods across borders has shrunk. Intermediate imports rose fast in the 20 years to 2008, but since then have dropped from 19 percent of world GDP to 17 percent (The Economist, January 26, 2019). The march of multinational firms has halted as the global corporate share of global profits of all listed firms has dropped from 33 percent in 2008 to 31 percent (The Economist, January 26, 2019). Long-term cross- 
border investment by all firms, known as Foreign Direct Investment (FDI), has tumbled from 3.5 percent of world GDP in 2007 to 1.3 percent in 2018 (The Economist, January 26, 2019). As crossborder trade and companies have stagnated relative to the economy, so too has the intensity of financial links. Cross-border bank loans have collapsed from 60 percent of GDP in 2006 to about 36 percent (The Economist, January 26, 2019). Excluding rickety European banks, they have been flat at 17 percent. Gross capital flows have fallen from a peak of 7 percent in early 2007 to 1.5 percent (The Economist, January 26, 2019). Since 2008 the share of economies converging from emerging economies to catch up with the rich world in terms of output per person using purchasing-power parity has fallen from 88 percent to 50 percent (The Economist, January 26, 2019). So in fact, almost all conventional measures of global trade and market integration have fallen. Tariffs have reached highest levels in the last 40 years and additional costs of trade have begun to be passed onto consumers (Profita, 2019). In the second half of 2018, the largest US companies lost about 6 billionor 3 percent - in profits due to tariffs (Profita, 2019; The Economist, January 26, 2016). US and Chinese investments in Europe have fallen dramatically, for instance, China's investment by 73 percent in 2018 (The Economist, January 26, 2019). The global value of foreign investment by multinationals decreased by 20 percent in the same year (The Economist, January 26, 2019). As the service sector appears to continue to expand, relocation for the sake of consumption has stagnated or declined as it is harder to relocate services (Buera \& Kaboski 2012; Echevarria 1997). Based on the last decade, The Economist (January 26, 2019) predicts a decline in exports from 28 to 23 percent of GDP over the next ten years, which would resemble a similar drop between 1929 and 1946.

Slowbalisation speaks to the fact that since the 2008 World Financial Recession, Asia's growth rates are slowing, cross-border investments, trade, bank loans and supply chains have been shrinking or stagnating relative to world GDP (The Economist, January 26, 2019). While one of the main benefits of globalization was that between 1990 and 2010 most emerging countries were able to close some of the gap with developed ones, a slowdown in globalization likely leads to a reversal in underdeveloped parts of the world catching up (The Economist, January 26, 2019). In addition to projected major political risks and the decline in socio-economic development, with the absence of a global cooperation, it will be more difficult to tackle and solve major coordination challenges such as climate change and climate refugees, immigration and tax evasion (Baldwin 2017; Profita 2019). This predicament is crucial if we seem to trade off environmental degradation with international development opportunities - the two most pressing obstacles for contemporary humankind (World Bank 2015 Development Report 2015).

Politically, where we seemed to have spent decades after two world wars to break down walls and pacify Europe in a Union, we are now back to building barriers faster than before (Profita 2019). Since 2009, the number of new free trade agreements between countries has plummeted and restrictions on trade have proliferated on duties, anti-dumping measures and on Non-Tariff Barriers to trade (NTBs). Bloomberg (O'Brien 2018) reports that the DHL monitor tracking shows that global trade is continuing to lose a little steam amid an escalating tariff battle between the world's biggest economies (Profita 2019). Media and news but also big data trends appear to have open gates to the world as never before while shrinking the number of local newspapers and media outlets (Hagey, Alpert \& Serkez 2019). Corporate greed and politics of fear are partially argued as socio-political trends around slowbalisation (Profita 2019). nternational remedies are called upon to ensure upholding the benefits of globalization in our commonly-shared fragile world to ensure continuous economic prosperity, societal advancement and humane dignity for all (Banerjee \& Moll 2010).

Yet, this is not the end of the story, as some globalization features still show rising integration. Technological advances, including mobile phones and especially the internet, have contributed to globalization by connecting people all over the globe. Innovation spurs companies to substitute labor while technology shocks drive economic growth, especially when technologies progressively reduce the physical work component (World Bank Report, 2008). While goods are not shipped around the globe in extensive global value chains, the consumers themselves have become yet more global. The World Wide Web links billions of people and devices, providing innumerable opportunities for the exchange of goods, services, cultural products, knowledge, and ideas. The internet connectivity and 
volume of data crossing borders has risen by 64 times, according to McKinsey, people appear to enjoy experiences abroad and consume data. Building dreams and hope based on information shared online, migration to the rich world has risen over the past decade. International parcels and flights are growing fast, almost exponentially. As exhibited in Graph 1 derived from the Economist, traditional globalization features have slowed while international parcel volume, data transfer and international air travel as well as migration to the developed world continues on a globalization course. At the same time, air travel is highest ever, indicating that while goods do not travel around the globe anymore and emerging economies seem to become more versatile in producing on their own for their own needs, human do for experiences and service consumption to an extent and degree as never before in history.

Graph 1: Global stops and starts derived from the Economist

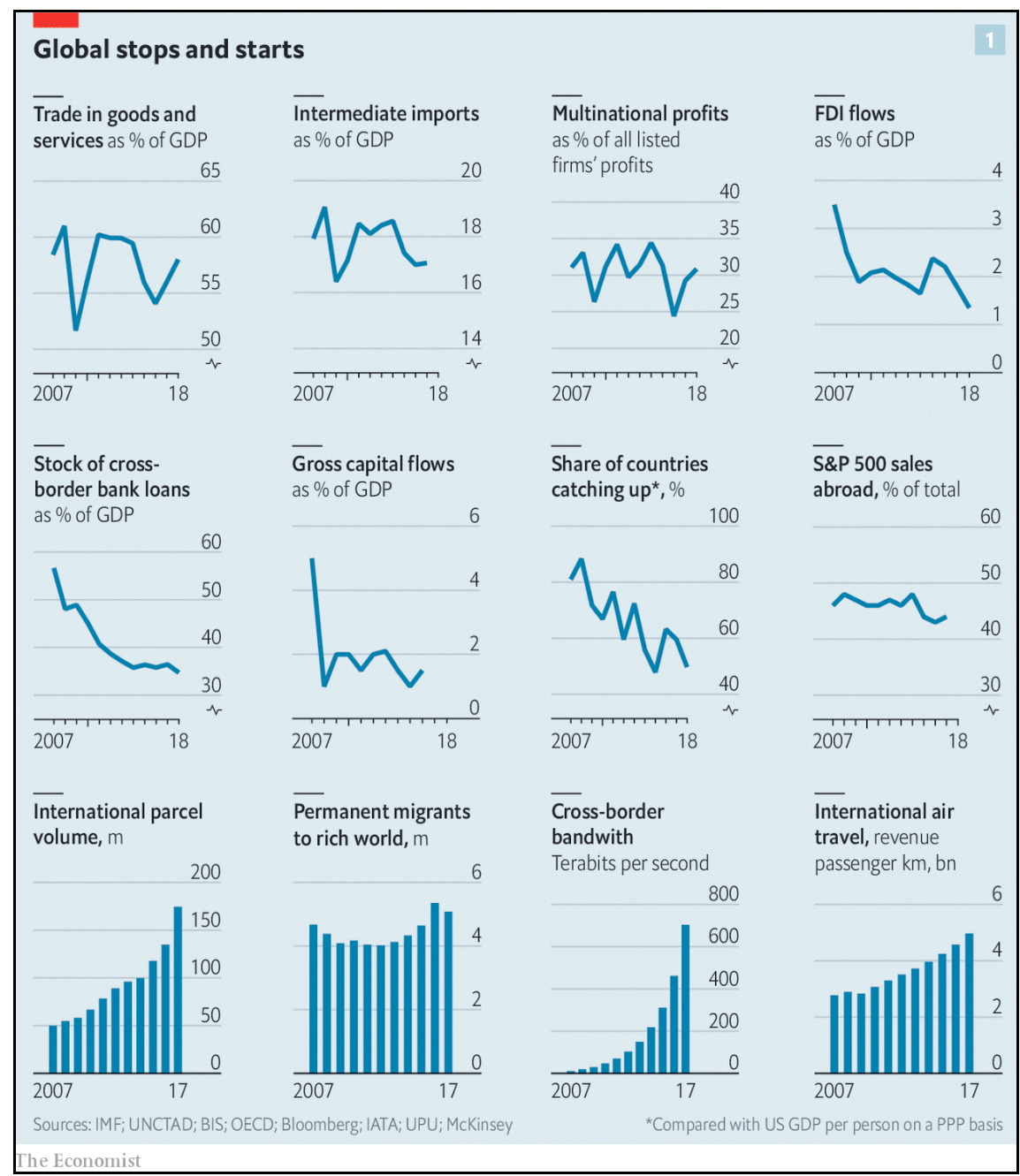

Source: Economist (https://www.economist.com/briefing/2019/01/24/globalisation-has-faltered)

This trend of polarization between ongoing polarization of globalization on data and people versus slowbalisation of traditional goods and services as well as finance is argued as first sign of AI entering economic production and changing goods and service trade. Technological and political factors could indicate a market disruption that has already begun and currently echoes in globalization versus slobwbalisation occurring parallel to each other. The currently described trend of slobwbalisation could just be a forerunner of the AI revolution market disruption about to take place that will create a world very different to the one we know.

With the ringing in AI revolution, technological development is bringing production and manufacturing closer to the end user. Fourth Industrial Revolution, robots are expected to become more efficient and affordable. With that, conventional globalization practices - such as offshoring manufacturing to cheap labor cost countries - will most likely decline. Reshoring will bring back 
production to where goods and services are actually and finally consumed. The most obvious example is energy and a prospective attempt to decentralize renewable energy generation. Your solar panel becomes more productive if energy need not be stored but simply can be shared with your neighbor when not needed it.

Currently reshoring appears to occur, in which domestic technology-enhanced production is favored over outsourcing to desolate low-skilled, low-income territories. AI holds the potential to replicate human existence but live eternally. $24 / 7$ working robots that can live eternally are expected to become the driver of industrialized economies and replace the majority of human workforce (Lucas 2004). 3D-printing techniques and nanotechnology that allow production to start at the molecular or even atomic level are fostering reshoring as relocating production sights from global value chain sights that were spread out during the golden years of globalization to where goods and services are consumed today. Reshoring of global production closer to where consumers are appears favorable in light of climate change and carbon emissions; yet shunning low skilled labor in developing parts of the world from production for globally operating multinationals may revert international development (Banerjee \& Duflo 2005; Greenwood \& Jovanovic 1990; Moll 2014; Mookherjee \& Napel 2007; Mookherjee \& Ray 2003). So while companies around the globe featured an offshoring trend during the golden age of globalization, contemporary reshoring and glocalization occurs (https://en.wikipedia.org/wiki/Glocalization). Slowbalisation appears to strengthen regional trade blocs, especially in Europe and Asia (Profita 2019; The Economist, January 26, 2019).

Corporations appear to be focusing their production back to where they serve their customers and consumers have recently gained substantial interest in more local products. There is a projected impact of robotic development on international trade. Robots are expected to be more accurate and work 24/7, while being less demanding than human workers. Millions of employees in the East may lose their jobs over the next few decades, substituted by robots in the West. In addition, advances in 3D printers may soon make it possible to substitute large factories with much smaller ones, closer to the consumer, where the manufacturing process is simplified thanks to the reproduction of models (Aghion et al. 2017). New materials could be manufactured near the consumer, in order to substitute natural materials that need to be transported from distant mines and deposits (Tybout 2000). Trade links within regional blocs may increase and blocks become more homogenous, both in Europe and Asia.

High-end production has discovered the luxury of opening consumers' eyes for the entire production and ensuring that corporate social responsibility is lived throughout the value change. Moreover, when companies bring production back into their countries for AI, unskilled workers lose out in the domestic markets while leaving behind markets that flourished due to outsourcing companies (Birdsall 2017). Reshoring mean that former outsourced tasks are simply performed by AI in high skilled interconnected countries, with whom low skilled workers in the developing world now will have to compete. The transition to the new globalization has caused the workers in developed markets to lose bargaining power as they now operate in the production phases that are most vulnerable to delocalization and automation, while the Western world will face competition with AI in wage-stagnating economies (Baldwin 2017; Barseghyan \& DiCecio 2011; Profita 2019). A trend which will - for instance - pit a 5G automated device pit against a low skilled worker in a desolate place on earth with not even internet access, which allows learning and productivity gains (Lucas \& Moll 2014). Slowbalisation and reshoring are thereby expected to widen the gap between the rich and the poor. AI entering our economies may lead to a trend of reshoring and thereby shunning away international low-cost production sights from global production. The global gap between AI automated hubs and non-automated places on earth will therefore likely increase in the years to come. So while reshoring offers opportunities of more sustainable production in light of climate change, when we consider the environmental impacts of shipping goods around the globe until they reach the end user; in the end, it also bears the risk of restricting global economic development. 


\section{Results}

In order to clarify if the currently detected slowbalisation trend is the first sign of a market disruption related to AI entering markets, the empirical investigation features Study 1 to (1) show that the currently detected polarization of globalization and slowbalisation trends is AI-market introduction driven. Study 1 validates the slowbalisation trend with particular focus on proving evidence for still ongoing globalization being connected to AI-led growth.

In order to consolidate the observation that there is a slowbalisation trend in conventional globalization parameters while globalization continues in the AI domain, a correlation study will be staged. As a proxy for AI entering economic markets, internet connectivity, as measured by the Global Connectivity Index (2018) will be related to GDP pillars of agriculture, industry and service sectors as derived from the World Bank dataset on GDP of the year 2017 and a cross-validation check be performed with the State of the Mobile Internet Connectivity 2018 Index (GSMA 2018). This measure should aid in understanding what GDP sectors AI is attributed to. Futher, the different components of the slowbalisation trend will be related to one another in a correlation study in order to see whether slowbalisation is a sign of AI entering markets and growth theory not being able to truly capture AI productivity. A trend of globalization still continuing in AI-featuring industries and countries will be highlighted by relating AI-integration with globalization hallmarks of capital and labor movements.

\section{Discussion}

In today's economy, robots and algorithms are taking over human decision-making tasks and entering the workforce. Most recently, big data has evolved to become a source of major assets and governments around the world are endeavoring to tax wealth creation from information transfer. This trend currently challenges conventional economic theory to capture growth based on purely capital and labor components. Algorithms, machine learning and big data gains but also the shared economy do not seem to be represented accurately in conventional growth theory components of capital and labor (Alvarez, Buera \& Lucas 2007).

Future research endeavors may therefore address inequality drawing on the future vision that central rational AI-hubs will outperform underdeveloped remote areas of the world even more in the digital age. Slowbalisation is projected to draw back outsourcing efforts and divide AI hubs from areas that are less connected. Following research should be concerned with the unprecedentedly high divide between skilled and unskilled labor and the diversion between AI hubs and non-AI territories. In the last four decades, the price of skilled labor has soared dramatically relatively to that of unskilled labor despite a major uprise in the relative supply of skills. The notion of skill-bias in growth theories has introduced the theoretical possibility that technological progress benefits only a sub-group of workers, placing technical change at the center of the income distribution debate (Goldberg \& Pavcnik 2007).

Organizational changes have lead to AI technologies reducing costs of communication, monitoring and supervision within the firm, which trigger a shift towards a new organizational design. The change towards AI induces an organizational shift towards skill-biased meritocracy. Endogenous technical progress leads to economic growth, but also generates wage inequality between low- and high skilled workers (Duarte \& Restuccia 2006; Murphy, Riddell \& Romer 1998; Parente \& Prescott 1993). Faster technical change increases the return to ability and increases wage inequality between, and also within, groups of high-skilled and unskilled workers (Galor \& Moav 2000). Future studies should integrate some of the contemporary inequality measurements such as the Palma ratio, financial development and wealth transfers in contemporary growth theories and measurement (Jacoby, 2008; Milanovic 2013; Piketty 2014). Wage inequality is only one way to assess inequality, but in order to get a richer picture of inequality derived from AI, future research may also consider inequality in wealth, health, status and within-group inequalities (Restuccia \& Urrutia 2001). Understanding the links between growth and inequality should also be placed in the different contexts of political, social and historical environments in order to derive inference about a successful introduction of AI into 
today's workforce and society. Finally, more research is recommended to model and maximize the novel production function including AI and information share - especially in light of G5 and the internet of things leading to a further connection and benefits from technology. All these novel developments may lead to a potential polarization between more efficient AI hubs and low skill low labor cost areas that may be shunned from economic growth due to a predicted reshoring trend coupled with AI economic dominance and unprecedented technology gains (Aghion \& Bolton 1997; Matsuyama 2008, 2011; Restuccia \& Rogerson 2017; Ventura,1997).

\section{References}

Aghion, P. \& Bolton, P. 1997. “A theory of trickle-down growth and development.” Review of Economic Studies 64(2): 151-172.

Aghion, P., Jones, B.F. \& Jones, Ch.I. 2017. Artificial Intelligence and economic growth. National Bureau of Economic Research working paper retrieved at https://www.nber.org/chapters/c14015

Alvarez, F., Buera, F. \& Lucas, R.E.(2007. Idea flows, economic growth, and trade. National Bureau of Economic Research working paper retrieved at https://www.nber.org/papers/w19667

Baldwin, R. 2017. The great conversion: Information technology and the new globalization. Cambridge, MA: Harvard University Press.

Banerjee, A. \& Duflo, E. 2005. "Growth theory through the lens of development economics." In P. Aghion \& S. Durlauf (Eds.), Handbook of Economic Growth, pp. 473-552. Amsterdam: Elsevier.

Banerjee, A. \& Moll, B. 2010. "Why does misallocation persist?" American Economic Journal: Macroeconomics 2(1): 189-206.

Barseghyan, L. \& DiCecio, R. 2011. "Entry costs, industry structure, and cross-country income and TFP differences." Journal of Economic Theory 146(5): 1828-1851.

Birdsall, N. 2017. "Middle Class: Winners or Losers in a Globalized World?" Center for Global Development. Available at https://www.cgdev.org/publication/middle-class-winners-or-losers-globalized-world.

Buera, F.J. \& Shin, Y. 2011. "Finance and development: A tale of two sectors." American Economic Review 101: 19642002.

Centeno, Miguel Angel, Creager, A.N., Elga, A., Felton, E., Katz, St.N., Massey, W.A. \& Shapiro, J.N. 2013. Global systemic risk: Proposal for a research community. Princeton University, NJ: Princeton Institute for International and Regional Studies working paper.

Centeno, Miguel Angel. \& Tham, Alexander. 2012. The emergence of risk in the global system. Princeton, NJ: Princeton University working paper.

Duarte, M. \& Rstuccia, D. 2006. "The productivity of nations.” Federal Reserve Bank Richmond Economic Quarterly 92 (3): 195-223.

Echevarria, C. 1997. "Changes in sectoral composition associated with economic growth." International Economic Review 38(2): 431-452.

Galor, O. \& Moav, O. 2000. “Ability biased technological transition, wage inequality and growth.” Quarterly Journal of Economics 115: 469-498.

Global Connectivity Index (GCI). n.d. "GCI Ranking Table." Available at https://www.huawei.com/minisite/gci/en/country-rankings.html.

Goldberg, K. \& Pavcnik, N. 2007. "The distributional effects of globalization in developing countries." Journal of Economic Literature 45(1): 39-82.

Greenwood, J. \& Jovanovic, B. 1990. "Financial development, growth, and the distribution of income." Journal of Political Economy $98(5,1): 1076-1107$.

GSMA. 2018. "State of Mobile Internet Connectivity 2018." Available at https://www.gsma.com/mobilefordevelopment/resources/state-of-mobile-internet-connectivity-2018/.

Hagey, K., Alpert, L.I. \& Serkez, Y. 2019. "In news industry, a stark divide between haves and have-nots: Local newspapers are failing to make the digital transition larger players did and are in danger of vanishing." The Wall Street Journal, May 4, 2019.

Harberger, A. (1998). A vision of the growth process. American Economic Review, 88, 1, 1-32.

Held, D. \& McGrew, A.G. (2007). A new world economic order? Global markets and state power: Beyond globalization/anti-globalization: Beyond the great divide. New York, NY: Polity.

Jacoby, H.G. 2008. "Food prices, wages, and welfare in rural India.” Economic Inquiry 54(1): 159-176.

Kirchler, E.M. 2011. Wirtschaftspsychologie: Individuen, Gruppen, Märkte, Staat. Göttingen: Hogrefe.

Lucas, R.E. 2004. "The industrial revolution: Past and future." Annual Report of the Federal Reserve Bank of Minneapolis, May, pp. 5-20.

Lucas, R.E. \& Moll, B. 2014. "Knowledge growth and the allocation of time." Journal of Political Economy 122(1): 1-51.

Matsuyama, K. 2008. "Structural change." In S. Durlauf \& L.E. Blume (Eds.), The New Palgrave Dictionary of Economics, pp. London: Palgrave-Macmillan. 
Matsuyama, K. 2011. "Imperfect credit markets, household wealth distribution, and development." Annual Review of Economics 3: 339-362.

Milanovic, B. 2013. "Global income inequality in numbers: In history and now.” Global Policy 4(2): 198-208.

Mohamed, A.M.I. 2016. Globalization and new international public works agreements in developing countries: An analytical perspective. London, UK: Routledge.

Moll, B. 2014. "Productivity losses from financial frictions: Can self-financing undo capital misallocations?" American Economic Review 104(10): 3186-3221.

Mookherjee, D. \& Napel, S. 2007. "Intergenerational mobility and macroeconomic history dependence." Journal of Economic Theory 137(1): 49-78.

Mookherjee, D. \& Ray, D. 2003. "Persistent inequality.” Review of Economic Studies 70: 369-393.

Murphy, K.M., Riddell, W.C. \& Romer, P.M. 1998. Wages, skills, and technology in the United States and Canada. National Bureau of Economic Research (NBER) Working Paper 6638 retrieved at https://www.nber.org/papers/w6638.pdf.

O’Brien, F. 2018. "Global Trade Growth Slowly Losing Steam as Business Feels Pinch.” Bloomberg. Available at www.bloomberg.com/news/articles/2018-09-27/global-trade-growth-slowly-losing-steam-as-business-feels-pinch

Parente, St. \& Prescott, E. 1993. "Changes in the wealth of nations.” Quarterly Review of Economics 17 (2): 3-16.

Piketty, Th. 2014. Capital in the twenty-first century. Cambridge, MA: Harvard University Press.

Profita, Sofia. 2019. Slowbalization and its risks. Columbia University working paper. New York, NY: Columbia University.

Restuccia, D. \& Rogerson, R. 2017. "The causes and costs of misallocation." Journal of Economic Perspectives 31(3): 151-174.

Restuccia, D. \& Urrutia, C. 2001. "Relative prices and investment rates." Journal of Monetary Economics 47(1): 93-121.

Rodrik, Dani. 2006. "Goodbye Washington consensus, hello Washington confusion? A review of the World Bank's economic growth in the 1990s: Learning from a decade of reform." Journal of Economic Literature 44(4): 973-987.

Tybout, J. 2000. "Manufacturing firms in developing countries: How well do they do, and why?" Journal of Economic Literature 38(1): 11-44.

Ventura, J. 1997. Growth and interdependence. The Quarterly Journal of Economics 112(1): 57-84.

World Bank 2015 Report (2015). Washington, D.C.: World Bank. 